\title{
Hard Water and Dyeing Properties: Effect of Pre- and Post-Mordanting on Dyeing Using Eucalyptus globulus and Curcuma longa Extracts
}

\author{
Sana Mahmood ${ }^{1}$, Shaukat Ali', M. Afzal Qamar'², M. Rizwan Ashraf', \\ Muhammad Atif ${ }^{1}$, Munawar Iqbal ${ }^{3 *}$, Tanveer Hussain ${ }^{4}$ \\ ${ }^{1}$ Department of Chemistry, University of Agriculture, Faisalabad \\ ${ }^{2}$ Government Postgraduate College Samanabad, Faisalabad \\ ${ }^{3}$ Department of Chemistry, The University of Lahore, Lahore, Pakistan \\ ${ }^{4}$ Department of Textile Chemistry, National Textile University, Faisalabad, Pakistan
}

Received: 9 August 2016

Accepted: 8 September 2016

\begin{abstract}
A laboratory-scale study was performed for fostering an eco-friendly approach by substituting synthetic colorant with natural plant extracts as dye source in the presence of hard water (prepared from $\mathrm{NaHCO}_{3}$, $\mathrm{MgSO}_{4}, \mathrm{CaSO}_{4}$, and $\mathrm{KCl}$ ). The dyeing behavior of cotton fabric was analyzed using extract from Eucalyptus globulus and Curcuma longa. Alum and ferrous sulphate were used as mordanting agents to mitigate the hard water effect on dyeing properties. The color strength and fastness properties of dyed cotton were studied. The hard water badly affected the color properties of fabric dyed with natural dyes. Mordant lessened the adverse effects of hard water, but not satisfactorily. The sequestering agent proved to be significant in mitigating the negative effect of hard water on fabric dyeing. Moreover, water hardness also adversely affected the extraction of natural dyes from Eucalyptus globulus and Curcuma longa; however, dye exhaustion was improved by mordant and the sequestering agent. Results revealed that the negative impact of hard water on dyeing properties can be mitigated using a sequestering agent.
\end{abstract}

Keywords: natural dyes, hard water, mordant, cotton fiber, color strength, sequestering agent

\section{Introduction}

Textile wet processing utilizes a huge amount of water, and the discharged water contains a significant amount

*e-mail: bosalvee@yahoo.com of salts used in the pre-treatment, bleaching, dyeing, and printing processes [1-4]. Hard water affects the dyeing process and, using optimized dyeing conditions, the adverse effect of water hardness can be avoided by chelating the metal ions contributing to hardness through sequestering agents, i.e., polyphosphates or amino carboxylic acids [5-8]. 
Plants are the enormous source of biological moieties with diverse applications [9-15]. Use of natural colorants also has varying influence on the dyeing behavior in the presence of hard water. Moreover, mordant such as alum, potassium dichromate and stannous chloride and dulling mordant such as cupric sulphate and iron sulphate are also in practice to mitigate the effect of hard water on dyeing properties. Moreover, methods of mordanting are also influential in producing the dyeing outcome like pre-mordanting, meta-mordanting and postmordanting [16]. However, for better dyeing process, selection of dye is the most important factor. Nowadays, safer and eco-friendly dyeing process is preferred, which can be fulfilled using natural sources. Plants are the most accessible and economically viable source of natural dyes [17].

Cotton fabric was dyed using Eucalyptus globulus and Curcuma longa extracts in the presence of hard water. We evaluated the mordent and sequestering agent's affects on dyeing properties. Our study was conducted in hard water of different strengths (hard and soft), and various process variables were optimized to achieve maximum color strength.

\section{Material and Methods}

\section{Hard and Soft Water}

Hard water of different strengths was prepared using $\mathrm{NaHCO}_{3}, \mathrm{MgSO}_{4}, \mathrm{CaSO}_{4}$, and $\mathrm{KCl}$. Hardness was confirmed by titrating it against $0.01 \mathrm{~N}$ solution of EDTA and the strengths we prepared are shown in Table 1.

\section{Extraction of Colorants with and without Sequestering Agents}

The extraction was carried out for 60,60 , and $90 \mathrm{~min}$ at a 1:20 M:L ratio for both the turmeric and eucalyptus with distilled water. The effect of temperature was studied at varying water hardness.

Extracts from both turmeric and eucalyptus were used for the dyeing process in different water types. A sequestering agent was added to see its effect $\left(\mathrm{FeSO}_{4}\right.$ and alum) on dyeing properties to mitigate the effect of hard water on the dyeing process. For the dyeing of cotton fabric, pre-mordanting and post-mordanting was done with alum and $\mathrm{FeSO}_{4}$ for both dyes. In pre-mordanting both the plant extract (colorant) was first treated with mordents and then employed for the dyeing using each hard water as precisely reported elsewhere [18].

\section{Dyeing of Fabric}

Dyeing cotton fabric (5 g) was carried out using 5\% turmeric and eucalyptus extracts in distilled water at a material-to-liquor ratio of 1:15 with alum and ferrous sulphate $30 \mathrm{~g} / \mathrm{L}$ and $20 \mathrm{~g} / \mathrm{L}$, respectively. The dyeing process of cotton fiber was done using an HT dyeing machine at the Color and Textile Laboratory, Department of Chemistry, University of Agriculture, Faisalabad.

\section{Washing Fastness and Rubbing Fastness}

The washing fastness of dyed fabric was evaluated using the ISO $105 \mathrm{CO}_{3}$ method. For this, $0.5 \mathrm{~g}$ dyed sample was placed between two pieces of size of undyed white samples and held together by stitching round the edges. Soap solution contained $5 \mathrm{~g}$ soap and $2 \mathrm{~g}$ of anhydrous sodium carbonate that was taken and volume was increased to $1 \mathrm{~L}$ with distilled water. Pre-heated soap solution $\left(\right.$ at $60^{\circ} \mathrm{C}$ ) in the ratio of 1:50 i.e., $0.5 \mathrm{~g} / 25 \mathrm{~mL}$ was taken in stainless steel glass and fabric was sandwiched and rotated at $60^{\circ} \mathrm{C}$ for $30 \mathrm{~min}$ in an $\mathrm{H}-\mathrm{T}$ dyeing machine. The specimen was removed, rinsed in cold and hot water, dried, assessed in its change in color, and rubbing fastness was estimated [19]. Rubbing fastness was analyzed using the ISO $105 \mathrm{x}-12$ method using a Crockmeter. A dry crocking test was performed using a $5 \times 13 \mathrm{~cm}$ piece of dyed fabric.

\section{Result and Discussion}

The Effect of Water Hardness on Extraction of Dye from Turmeric and Eucalyptus Bark

The data for extraction for turmeric at different times $(30,60$, and $90 \mathrm{~min})$ is presented in Fig. 1a with various hard water as compared to control. The optimized conditions were found to be M:L $1: 20$, temperature $90^{\circ} \mathrm{C}$ and $60 \mathrm{~min}$ reaction time. Hard water affected the dye

Table 1. Water characteristics used for dying.

\begin{tabular}{|c|c|c|c|c|c|c|}
\hline \multirow{2}{*}{ Hardness } & \multicolumn{4}{|c|}{ Reagent added (mg/L) } & \multicolumn{2}{c|}{ Water quality } \\
\cline { 2 - 7 } & $\mathrm{NaHCO}_{3}$ & $\mathrm{MgSO}_{4}$ & $\mathrm{CaSO}_{4}$ & $\mathrm{KCl}$ & $\mathrm{pH}$ & Hardness \\
\hline Very soft & 12 & 7.5 & 7.5 & 0.5 & $6.4-6.8$ & $10-13$ \\
\hline Soft & 48 & 30 & 30 & 2.0 & $7.2-7.6$ & $40-48$ \\
\hline Moderate hard & 96 & 60 & 60 & 4.0 & $7.4-7.8$ & $80-100$ \\
\hline Hard & 192 & 120 & 120 & 8.0 & $7.6-8.0$ & $160-180$ \\
\hline Very hard & 384 & 240 & 240 & 16.0 & $8.0-8.4$ & $280-320$ \\
\hline
\end{tabular}


Table 2. Effect of hard water on dyeing properties of cotton fabric dyed with turmeric and eucalyptus extracts.

\begin{tabular}{|c|c|c|c|c|c|c|c|c|c|c|}
\hline \multirow{2}{*}{$\begin{array}{l}\text { Water hardness } \\
\qquad(\mathrm{mg} / \mathrm{L})\end{array}$} & \multicolumn{5}{|c|}{ Turmeric dye } & \multicolumn{5}{|c|}{ Eucalyptus dye } \\
\hline & $\mathrm{L}^{*}$ & $a^{*}$ & $b^{*}$ & $\mathrm{C}^{*}$ & $\mathrm{~h}$ & $\mathrm{~L}^{*}$ & $a^{*}$ & $\mathrm{~b}^{*}$ & $\mathrm{C}^{*}$ & $\mathrm{~h}$ \\
\hline 0.00 & 70.54 & 4.36 & 62.98 & 51.29 & 88.77 & 46.22 & 8.23 & 19.54 & 21.2 & 67.15 \\
\hline \multirow{3}{*}{90.90} & 59.56 & 1.17 & 55.10 & 48.50 & 86.33 & 63.29 & 6.48 & 17.95 & 19.08 & 70.17 \\
\hline & 58.59 & 0.59 & 56.75 & 50.59 & 76.49 & 68.49 & 5.87 & 16.71 & 20.25 & 74.22 \\
\hline & 67.14 & 1.22 & 59.43 & 47.91 & 86.42 & 63.91 & 6.04 & 17.68 & 18.69 & 71.14 \\
\hline \multirow{3}{*}{272.72} & 50.91 & 3.22 & 58.67 & 44.35 & 86.50 & 64.19 & 6.32 & 17.43 & 18.54 & 70.07 \\
\hline & 60.09 & 3.5 & 52.5 & 42.95 & 85.00 & 65.05 & 5.64 & 16.8 & 17.72 & 71.44 \\
\hline & 57.96 & 2.31 & 55.62 & 41.29 & 82.10 & 64.29 & 6.3 & 17.21 & 18.33 & 69.89 \\
\hline \multirow{3}{*}{454.54} & 79.71 & 2.11 & 55.43 & 48.50 & 81.56 & 64.77 & 6.29 & 16.68 & 17.83 & 69.33 \\
\hline & 78.59 & 1.93 & 56.72 & 50.59 & 84.79 & 63.67 & 6.78 & 16.95 & 18.26 & 68.2 \\
\hline & 76.22 & 1.02 & 56.43 & 45.24 & 85.87 & 63.76 & 6.8 & 18.43 & 19.65 & 69.74 \\
\hline
\end{tabular}

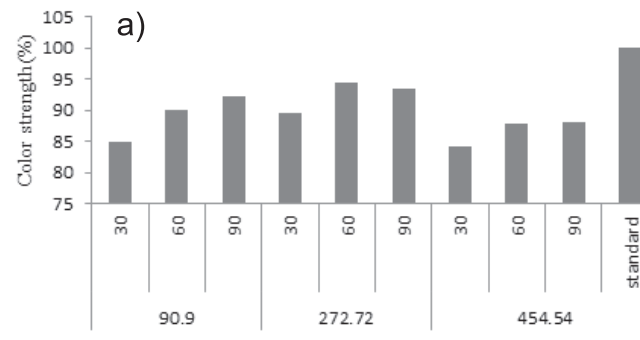

Extraction time ( $\mathrm{min})$ and hard water strength $\left(\mathrm{NaHCO}_{3}, \mathrm{MgSO}_{4}\right.$, $\mathrm{CaSO}_{4}$ and $\mathrm{KCl} \mathrm{mg} / \mathrm{L}$ in combination)
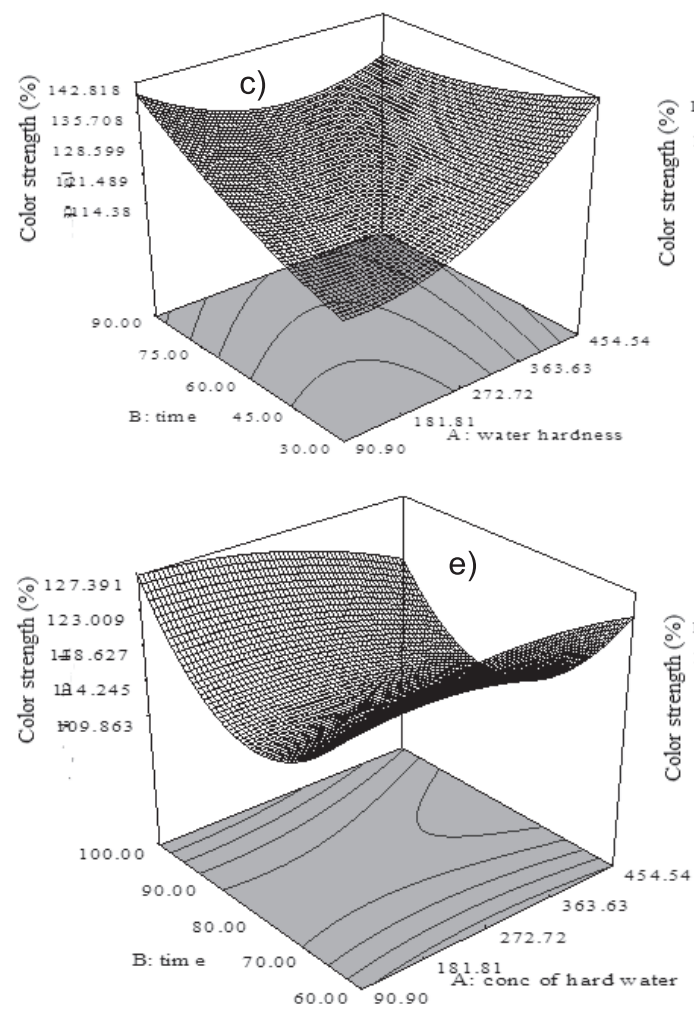

b)

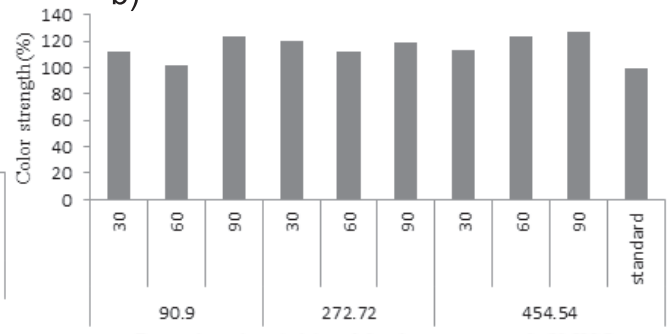

Extraction time $(\mathrm{min})$ and hard water strength $\left(\mathrm{NaHCO}_{3}\right.$ $\mathrm{MgSO}_{4}, \mathrm{CaSO}_{4}$ and $\mathrm{KCl} \mathrm{mg} / \mathrm{L}$ in combination)
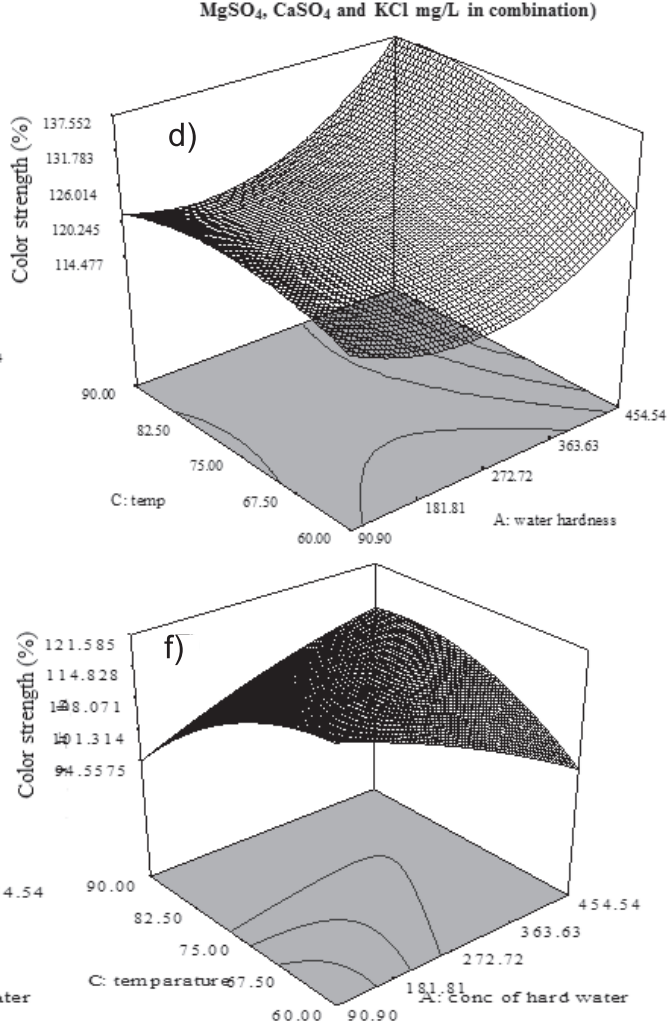

Fig. 1. Effects of water hardness: a) on color strength of cotton dyed with Eucalyptus extract, b) on color strength of cotton dyed with Eucalyptus extract, c) as a function of time on color strength using turmeric extracts, d) as a function of time on color strength using Eucalyptus extracts, e) on color strength at different temperatures for turmeric extracts, and f) on color strength at different temperatures for Eucalyptus extracts. 
extraction from both turmeric and eucalyptus. As hardness increased, the color strength decreased significantly, which might be due to metal ions that could aggregate with dye molecules and decrease dye exhaustion [18]. The yellowish tone was decreased prominently since the colorimetric values like $\mathrm{a}^{*}$ decreased from 4.36 to 1.17 , 0.59 and 1.22 by increasing the time from 30 to $90 \mathrm{~min}$ with water hardness scale 90.90 (mg/L) (Table 2). Other hardness scales also showed adverse and variable impact on the color strength (Fig. 1a). Low color strength during extraction from turmeric with hard water is attributed to $\mathrm{pH}$ of the extraction medium that is alkaline and consequently destabilizes the curcumin (main component of turmeric dye). Our results were in line with previous reports. i.e., negative effect of hardness on color strength $(\mathrm{K} / \mathrm{S})$ was reported for reactive dye for cotton dyeing [20]. In contrast to turmeric extracts, the extraction of dye from eucalyptus in the presence of hard water hard showed less impact on color strength. As can be seen from Fig. 1b), extraction of dye for different time intervals showed variable impact on extraction of dye at different hardness values. Color strength increased as water hardness scale increases from 90.90 to $454.54 \mathrm{mg} / \mathrm{L}$, which enhanced the alkaline nature of extraction medium. This increase in extraction quality and color strength might be due to quercetin (the main component of dye present in eucalyptus). This component is anionic in nature in aqueous form that is more stable in alkaline medium and more soluble in hard water (Table 2). Results showed that $L^{*}$ values increased and $H$ values higher than standard indicates more yellowish tone in alkaline medium.

\section{Effect of Temperature on Dyeing in Hard Water}

Dyeing with both types of extracts was carried out for $30-90 \mathrm{~min}$ in temperature range of $60-80^{\circ} \mathrm{C}$ in the presence of hard water (90.90-454.54 mg/L). The percentage color strength increased slightly in the presence of hard water when fabric was dyed with turmeric extract. The color coordinates, $\mathrm{L}^{*}$ indicated that color was lighter and lower values of $\mathrm{a}^{*}$ and higher values of $\mathrm{b}^{*}$ indicate color was yellowish instead of redder. Higher values for $\mathrm{H}$ indicate brightness and reaction time and temperature effect for different dyeing times using turmeric extracts in hard water scales on color strength are depicted in Figs. 1c) and 1d), respectively. The improvement in color strength might be attributed to a marked reduction in Zeta potential of fabric. The decrease in zeta potential is due to the strong attractive forces between the cation and the negatively charged surface of cotton. Under such conditions, the cation could partially screen the fiber-water interface of cotton [21]. The cations crowding toward fiber could neutralize the negative charges on surface and reduce the repulsive forces between cotton and dye anions [22]. Consequently, there is an increase in the chemical potential of dyeing, which in turn leads to increased color strength. Dyeing of cotton fabric with eucalyptus extracts as a function of time and temperature also showed the same trends and responses as shown in Figs 1e) and 1f).
Color strength values increased when water hardness increased. But color coordinates showed a slight change as compared to fabric dyed with turmeric extract. Values of $a^{*}$ and $b^{*}$ indicated that tone of the color was redder and more yellowish, respectively, which were comparable with standard values. The value of $\mathrm{C}^{*}$ was in the range of 17-20, which is also a good indication of brightness. A significant increase in color strength was found when temperature rose. However, dyeing time imposed a negative effect on dyeing quality in the presence of hard water. These results are in line with previous reports [23].

\section{Effect of Pre-Mordanting on Dyeing Properties}

We investigated the effect of alum and $\mathrm{FeSO}_{4}(5 \%$ solution) as pre-mordant on dyeing in the presence of hard water at $30^{\circ} \mathrm{C}$ and $45 \mathrm{~min}$ dyeing time. The pre-mordanting effect was significant on dyeing properties in the presence of hard water (turmeric extract). The color strength increased when alum was employed as pre-mordant (Fig. 2a), and in the case of eucalyptus the Alum effect was insignificant. The negative impact might be due to insoluble complex formation of alum with dye molecules and consequently dye uptake decreased [24]. As water hardness increased, we observed a more adverse effect on color strength. Color coordinate values, i.e., a* revealed a negative effect and color tone was greenish and positive values of $b^{*}$ indicates yellowish color tone (Table 3 ). In the case of $\mathrm{FeSO}_{4}$ the color strength values were recorded low as compared to standard both for turmeric and eucalyptus extracts (Fig. 2b). The color coordinate values indicated an insignificant effect on color coordinates (Table 3). The chroma ${ }^{*} \mathrm{C}$ values for all fabric samples was fair. However, brilliancy was affected negatively. $\mathrm{FeSO}_{4}$ as mordant with various hard water scales and effect on color properties was insignificant. Previously, it has also been reported that mordant could not work properly in the presence of hard water [25], and similar effect was observed in the present investigation, and this negative effect has been correlated with insolubility and aggregation of dye molecules, which reduced the dye uptake [26].

\section{Effect of Post-Mordanting on Dyeing Properties}

Post-mordanting was also employed to investigate the impact on color for both types of extracts, and responses are shown in Figs. 2c-d. The addition of a sequestering agent markedly improves color strength. Both turmeric and eucalyptus extracts showed higher color strength values versus standard both for alum and $\mathrm{FeSO}_{4}$. The dyeing with turmeric extract showed significantly higher color strength in the presence of hard water, which revealed that postmordanting considerably mitigate the hard water effect on color strength. Color coordinate values also showed good values, and higher $\mathrm{L}^{*}$ value indicate lightness of the color 

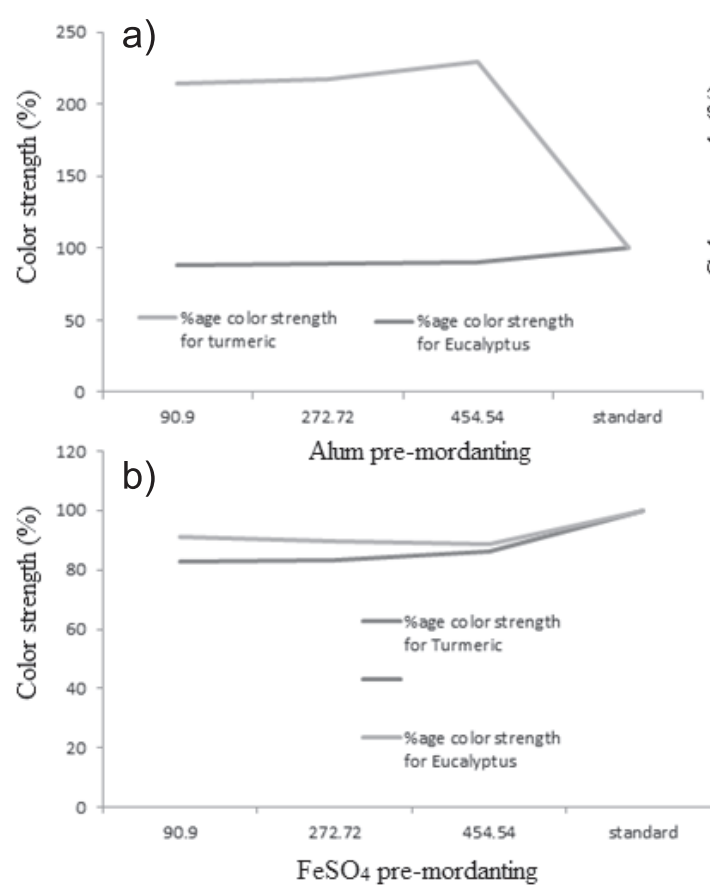

c)

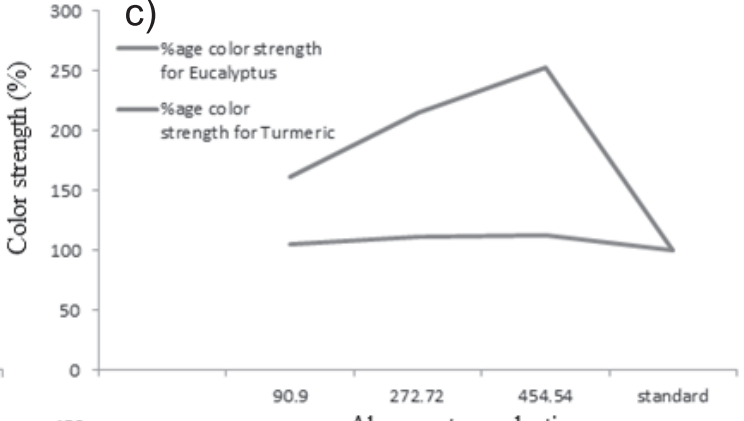

d) Alum post-mordanting

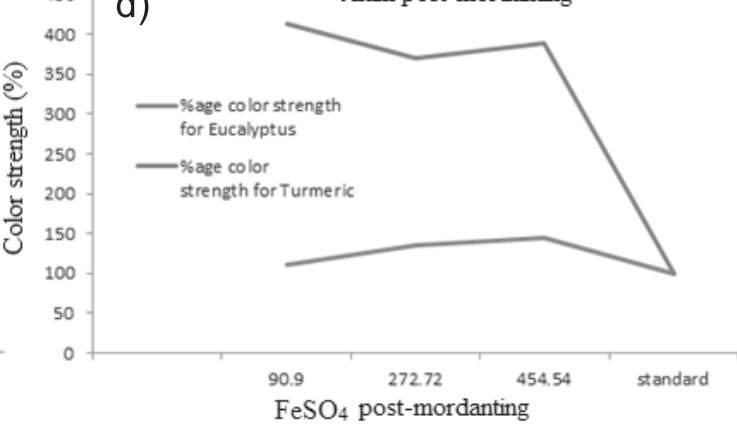

Fig. 2. Effects of: a) alum pre-mordanting on the dyeing process, b) $\mathrm{FeSO}_{4}$ pre-mordanting on the dyeing process, c) alum post-mordanting on dyeing process, and d) $\mathrm{FeSO}_{4}$ post-mordanting on the dyeing process.

amplified as compared to control, which showed highly deep color. Decreased color tone ( $\left.\mathrm{a}^{*}\right)$ was an indication that color was less red and more green; on the other hand, $b^{*}$ indicates the yellowish color of dyed cotton. The $C^{*}$ values revealed fairly good brightness as compared to control. Previously, it has been reported that sequestering agents have an enhancing effect on color strength and this behavior is attributed to extraction conditions to stripping off the metal ions with sequestering agents that ultimately improve color quality and extraction efficiencies [5]. In the present study, significantly improved color quality is also an indication of hard water mitigating the effect of sequestering agents.

\section{Color Properties}

Washing and rubbing fastness tests were performed to check the colorfastness properties, which were recorded. For eucalyptus, rubbing fastness was in the range of 4-5 and washing fastness value was 4 in distilled water, and in hard water these values were 3-4 and 3-4, respectively. In the case of turmeric extrac, these values were 3 and 3-5 for washing and rubbing fastness in distilled water, and 1-2 and 3-4 in hard water, respectively. It was observed that water hardness had an adverse effect on washing and rubbing fastness when fabric was dyed with both turmeric

Table 3. Effect of pre-mordanting on dyeing properties of cotton fabric dyed with turmeric and eucalyptus extracts.

\begin{tabular}{|c|c|c|c|c|c|c|c|c|c|c|}
\hline \multicolumn{11}{|c|}{ Alum } \\
\hline \multirow{2}{*}{$\begin{array}{l}\text { Water hardness } \\
\qquad(\mathrm{mg} / \mathrm{L})\end{array}$} & \multicolumn{5}{|c|}{ Turmeric dye } & \multicolumn{5}{|c|}{ Eucalyptus dye } \\
\hline & $\mathrm{L}^{*}$ & $a^{*}$ & $b^{*}$ & $\mathrm{C}^{*}$ & $\mathrm{~h}$ & $\mathrm{~L}^{*}$ & $a^{*}$ & $b^{*}$ & $\mathrm{C}^{*}$ & $\mathrm{~h}$ \\
\hline 0.00 & 78.90 & 7.34 & 51.2 & 51.3 & 96.74 & 57.31 & 5.56 & 19.43 & 21.22 & 68.32 \\
\hline 90.90 & 68.26 & 2.47 & 32.4 & 32.5 & 86.68 & 58.47 & 7.85 & 23.89 & 25.14 & 71.82 \\
\hline 272.72 & 65.32 & -0.3 & 34.4 & 34.4 & 80.42 & 57.59 & 8.10 & 23.95 & 25.28 & 71.32 \\
\hline 454.54 & 67.64 & -5.0 & 34.6 & 32.9 & 86.74 & 57.39 & 5.89 & 23.02 & 24.93 & 72.15 \\
\hline \multicolumn{11}{|c|}{$\mathrm{FeSo}_{4}$} \\
\hline 0.00 & 79.98 & 6.54 & 67.22 & 67.45 & 95.15 & 42.65 & 4.75 & 13.22 & 16.88 & 79.70 \\
\hline 90.90 & 67.9 & 3.77 & 40.26 & 40.44 & 84.65 & 35.19 & 5.78 & 14.23 & 15.36 & 67.89 \\
\hline 272.72 & 68.43 & 2.67 & 39.57 & 39.66 & 86.14 & 33.19 & 5.78 & 14.88 & 15.97 & 68.76 \\
\hline 454.54 & 69.02 & 3.38 & 41.22 & 41.36 & 85.31 & 39.74 & 6.82 & 15.35 & 16.79 & 66.05 \\
\hline
\end{tabular}


and eucalyptus extracts. Therefore, based on this study, the use of mordanting/sequestering agent is suggested to enhance the dye uptake and previous studies also revealed a similar trend that mordanting/sequestering can be used to enhance the color strength and color properties [27-36], and in view of current environmental pollution [37-50], the natural sources should be preferred to avoid a negative impact on the environment.

\section{Conclusions}

The dyeing behavior of cotton fabric was analyzed using Eucalyptus globulus and Curcuma longa extracts in the presence of hard water using mordanting/sequestering agents. The color strength and fastness properties revealed that hard water badly affected fabric properties dyed with natural dyes. Mordanting/sequestering agents proved to be helpful in mitigating the negative effect of hard water on dyeing properties. Based on the findings of the present investigation, we concluded that hard water has a negative impact on dyeing properties, which can be minimized by using a mordanting/sequestering agent to enhance the efficiency of natural dyes.

\section{References}

1. SHAIKH M.A. Water conservation in textile industry. Pak. Text. J. 9, 48, 2009.

2. CHEN Y., HE L., LU H., LI J. Bi-Level decision-making approach for GHG emissions control and municipal solid waste management under parameter uncertainty: A case study in Beijing, China. Pol. J. Environ. Stud. 25, 1435, 2016.

3. DEMIR N.M. Experimental study of factors that affect iron and manganese removal in slow sand filters and identification of responsible microbial species. Pol. J. Environ. Stud. 25, 1453, 2016.

4. KWAŚNY J., BALCERZAK W. Sorbents used for biogas desulfurization in the adsorption process. Pol. J. Environ. Stud. 25, 37, 2016.

5. IMTIAZUDDIN S., TIKI M.S., KANWALA. Importance of sequestering agent in textile processing. Pak. Text. J. 58, 10, 2009.

6. HUA Z., YINGHUI J., TAO Y., MIN W., GUANGXUN S., MINGJUN D. Heavy metal concentrations and risk assessment of sediments and surface water of the Gan River, China. Pol. J. Environ. Stud. 25, 1529, 2016.

7. JIANG H., ZENG Y., NIE H., LI Y., DING J., ZHOU $\mathrm{H}$. $\mathrm{NaOH}$ pretreatment of wheat straw at a mesophilic temperature: Effect on hydrolysis and loss of organic carbon. Pol. J. Environ. Stud. 25, 1541, 2016.

8. GHASEMI M.K, YUSUFF R.B.M. Advantages and disadvantages of healthcare waste treatment and disposal alternatives: Malaysian scenario. Pol. J. Environ. Stud. 25, 17, 2016.

9. ADARAMOLA B., ONIGBINDE A. Influence of extraction technique on the mineral content and antioxidant capacity of edible oil extracted from ginger rhizome. Chem. Int. 3, $1,2017$.

10. ASIF M. Pharmacologically potentials of different substituted coumarin derivatives. Chem. Int. 1, 1, 2015.
11. ASIF M. Chemistry and antioxidant activity of plants containing some phenolic compounds. Chem. Int. 1, 35, 2015.

12. ASIF M. Antiviral and antiparasitic activities of various substituted triazole derivatives: A mini. Chem. Int. 1, 71, 2015.

13. ASIF M. Chemical characteristics and nutritional potentials of unsaturated fatty acids. Chem. Int. 1, 118, 2015.

14. ASIF M. Anti-tubercular activity of some six membered heterocycle compounds. Chem. Int. 1, 134, 2015.

15. ASIF M. Anti-neuropathic and anticonvulsant activities of various substituted triazoles analogues. Chem. Int. 1, 174, 2015.

16. SHENHNAI V. Technology of textile processing. II, 159, 1997.

17. NAGARAJAN S., KUBRA I.R., RAO L. Separation of curcuminoids enriched fraction from spent turmeric oleoresin and its antioxidant potential. J. Food Sci. 75, H158, 2010.

18. MOIZ A., AHMED M.A., KAUSAR N., AHMED K., SOHAIL M. Study the effect of metal ion on wool fabric dyeing with tea as natural dye. J. Saudi Chem. Soc. 14, 69, 2010.

19. UMBREEN S., ALI S., HUSSAIN T., NAWAZ R. Dyeing properties of natural dyes extracted from turmeric and their comparison with reactive dyeing. Res. J. Text. Apparel. 12, $1,2008$.

20. SHINDE T., MARATHE R., DORUGADE V.A. Effect of water hardness on reactive dyeing of cotton. Int. J. Text. Eng. Process. 1, 28, 2015.

21. RISTIC N., TARBUK A., GRANCARIC A.M., RISTIC I., SMELCEROVIC M. Interface phenomena and dyeability with reactive dyes of cationized cotton/Fenomene de interfata si capacitatea de vopsire cu coloranti reactivi a bumbacului cationizat. Ind. Text. 65, 220, 2014.

22. KAN C.W. Electrokinetic Study of Water Hardness during Acid Dyeing with Silk. Fibres \& Textiles in Eastern Europe. AUTEX Res. J. 8, 54, 2008.

23. NAGIA F., EL-MOHAMEDY R. Dyeing of wool with natural anthraquinone dyes from Fusarium oxysporum. Dye. Pigment. 75, 550, 2007.

24. CRINI G., BADOT P.M. Application of chitosan, a natural aminopolysaccharide, for dye removal from aqueous solutions by adsorption processes using batch studies: A review of recent literature. Prog. Poly. Sci. 33, 399, 2008.

25. NAZ S., BHATTI I.A., ADEEL S. Dyeing properties of cotton fabric using un-irradiated and gamma irradiated extracts of Eucalyptus camaldulensis bark powder. Ind. J. Fibre Text. Res. 36, 132, 2011.

26. BECHTOLD T., TURCANU A., GANGLBERGER E., GEISSLER S. Natural dyes in modern textile dyehouses how to combine experiences of two centuries to meet the demands of the future. J. Clean. Product. 11, 499, 2003.

27. SZCZEPAŃSKA N., OWCZAREK K., KUDŁAK B., POKRYWKA A., MAZERSKA Z., GAŁUSZKA A., NAMIECENIK J. Analysis and bioanalysis: an effective tool for data collection of environmental conditions and processes. Pol. J. Environ. Stud. 25, 45, 2016.

28. GHANEM K.M., AL-GARNI S.M., AL-ZAHRANI M.A. Bioremediation of diesel fuel by fungal consortium using statistical experimental designs. Pol. J. Environ. Stud. 25, 97, 2016.

29. HAI T., WEN-CHENG P., CHANG-FENG C., JIAN-PING X., WEN-JUN H. Remediation of acid mine drainage based on a novel coupled membrane-free microbial fuel cell with permeable reactive barrier system. Pol. J. Environ. Stud. 25, 107, 2016. 
30. HE Y., WANG F., TIAN P., MU X.M., GAO P., ZHAO G.J., WU Y.P. Impact assessment of human activities on runoff and sediment of Beiluo River in the Yellow River based on paired years of similar climate. Pol. J. Environ. Stud. 25, 121, 2016.

31. ADAMCOVÁ D., VAVERKOVÁ M.D., STEJSKAL B., BROUSKOVA E. Household solid waste composition focusing on hazardous waste. Pol. J. Environ. Stud. 25, 487, 2016.

32. DARGAHI A., GOLESTANIFAR H., DARVISHI P., KARAMI A., HASAN S.H., POORMOHAMMADI A., BEHZADNIA A. An investigation and comparison of removing heavy metals (lead and chromium) from aqueous solutions using magnesium oxide nanoparticles. Pol. J. Environ. Stud. 25, 557, 2016.

33. DAUD M.K., HASSAN S., AZIZULLAH A., JAMIL M., REHAN N., IRUM R., QAISER M.K., ZHU S.J. Physiological, biochemical, and genotoxic effects of wastewater on maize seedlings. Pol. J. Environ. Stud. 25, $563,2016$.

34. HUSSAIN S., NAEEM M., CHAUDHRY M.N. Estimation of residual antibiotics in pharmaceutical effluents and their fate in affected areas. Pol. J. Environ. Stud. 25, 607, 2016.

35. KALAJI H.M., SYTAR O., BRESTIC M., SAMBORSKA I.A., CETNER M.D., CARPENTIER C. Risk assessment of urban lake water quality based on in-situ cyanobacterial and total chlorophyll-a monitoring. Pol. J. Environ. Stud. 25, 2016.

36. NIE F., ZHOU Y., LIU R., LIU Z., HUANG D. Pollutant removal and PCR-DGGE analysis of microbial community structural changes in an integrated verticalflow constructed wetland. Pol. J. Environ. Stud. 25, 655, 2016.

37. BABARINDE A., OGUNDIPE, K.E.M.I., SANGOSANYA K.T., AKINTOLA B.D., ELIZABETH HASSAN A-O. Comparative study on the biosorption of $\mathrm{Pb}(\mathrm{II}), \mathrm{Cd}(\mathrm{II})$ and $\mathrm{Zn}$ (II) using Lemon grass (Cymbopogon citratus): kinetics, isotherms and thermodynamics. Chem. Int. 2, 89, 2016.
38. BABARINDE A., ONYIAOCHA G.O. Equilibrium sorption of divalent metal ions onto groundnut (Arachis hypogaea) shell: kinetics, isotherm and thermodynamics. Chem. Int. 2, 37, 2016.

39. GANGADHARA R., PRASAD N. Studies on optimization of transesterification of certain oils to produce biodiesel. Chem. Int. 2, 59, 2016.

40. IQBAL M., KHERA R.A. Adsorption of copper and lead in single and binary metal system onto Fumaria indica biomass. Chem. Int. 1, 157b, 2015.

41. JAFARINEJAD S. Control and treatment of sulfur compounds specially sulfur oxides ( $\mathrm{SOx}$ ) emissions from the petroleum industry: a review. Chem. Int. 2, 242, 2016.

42. JAMAL M.A., MUNEER M., IQBAL M. Photo-degradation of monoazo dye blue 13 using advanced oxidation process. Chem. Int. 1, 12, 2015.

43. MAJOLAGBE A.O., ADEYI A.A., OSIBANJO O. Vulnerability assessment of groundwater pollution in the vicinity of an active dumpsite (Olusosun), Lagos, Nigeria. Chem. Int. 2, 232, 2016.

44. PETER U.C., CHINEDU U. Model prediction for constant area, variable pressure drop in orifice plate characteristics in flow system. Chem. Int. 2, 80, 2016.

45. QURESHI K., AHMAD M., BHATTI I., IQBAL M., KHAN A. Cytotoxicity reduction of wastewater treated by advanced oxidation process. Chem. Int. 1, 53, 2015.

46. SAYED M. Efficient removal of phenol from aqueous solution by the pulsed high-voltage discharge process in the presence of $\mathrm{H}_{2} \mathrm{O}_{2}$. Chem. Int. 1, 81, 2015.

47. UKPAKA C. Development of model for bioremediation of crude oil using moringa extract. Chem. Int. 2, 19, 2016.

48. UKPAKA C. Predictive model on the effect of restrictor on transfer function parameters on pneumatic control system. Chem. Int. 2, 128, 2016.

49. UKPAKA C. Empirical model approach for the evaluation of $\mathrm{pH}$ and conductivity on pollutant diffusion in soil environment. Chem. Int. 2, 267, 2016.

50. UKPAKA C. BTX Degradation: The concept of microbial integration. Chem. Int. 3, 8, 2016. 